\title{
Five springtail (Collembola) species inhabiting heathlands in Poland
}

\section{Michał Furgol, Agata Piwnik \& Konrad Wiśniewski}

Furgoł, M., Piwnik, A. \& Wiśniewski, K. 2019: Five springtail (Collembola) species inhabiting heathlands in Poland. - Entomol. Fennica 30: 186-195. doi: https://doi.org/10.33338/ef.87176

We report the presence of five Collembola species from western Poland, three of which were recorded in this country for the first time - Bourletiella pistillum Gisin, 1964 (Bourletiellidae), Lepidocyrtus tellecheae Arbea \& Jordana 1990 (Entomobryidae) and Isotoma caerulea Bourlet, 1839 (Isotomidae). Seira dollfusi Carl, 1899 (Entomobryidae) was earlier known solely from a single, old report. Pachyotoma topsenti (Denis, 1948) (Isotomidae) is generally considered a rare species in the region. Though generally infrequently encountered, all five species occur in very high numbers in our plots and they are among the dominant springtails. The habitats surveyed in the study, i.e. dry Calluna-heathlands and their accompanying habitats are endangered in Central Europe and require active management. In one of the studied plots, a prescribed burn was applied to rejuvenate the heather. We discuss the distribution and habitat preferences of the five species in the European context and their possible significance as indicators of different habitat types.

M. Furgot (ORCID: 0000-0001-8723-6363) \& A. Piwnik (ORCID: 0000-00022407-5037), Department of Invertebrate Biology, Evolution and Conservation, Institute of Environmental Biology, Faculty of Biological Sciences, University of Wrocław, Przybyszewskiego 65, 51-148 Wrocław, Poland; E-mails: michalfurgol5@gmail.com \&agata.piwnik@uwr.edu.pl

K. Wiśniewski (ORCID: 0000-0002-6780-3292), Department of Zoology, Institute of Biology and Environmental Protection, Faculty of Mathematics and Natural Sciences, Pomeranian University in Stupsk, Arciszewskiego 22b, 76-200 Stupsk, Poland; E-mail: konwisniew@gmail.com

Received 1 February 2019, accepted 18 June 2019

\section{Introduction}

Calluna-heathlands and their associated habitats may host highly diverse, specific and endangered invertebrate fauna (Usher 1992), which has been observed in some different groups, such as carabids (Schirmel 2010, Buchholz et al. 2013), some other insect taxa (Swengel 2001) and spiders (Krause \& Assmann 2016). The springtails, one of the most interesting and diverse arthropod groups, were largely neglected as far as research in heathlands are considered, although some data have already been published (Petersen 1995, Shaw 1997). Dry heathlands are associated with sandy areas, such as dunes and pioneer grasslands. The springtail fauna of these habitats seems to be equally interesting (Sławska 1996, Russell 2008, Piwnik \& Skarżyński 2011, 2015). 
Collembola are abundant in a variety of habitats, their assemblages are often rich in species, and therefore they may be used as indicators of habitats or change of habitat quality (Ponge et al. 2008, Dunger \& Voigtländer 2009). In addition, the composition of their assemblages may reflect the intensity of some disturbances, e.g. fire (Huebner et al. 2012). Little is known about the biology of many springtail species, which impairs further analysis of their plausible role as indicator organisms.

Dry heathlands in Poland with compact Calluna vulgaris (L.) hull thicket that cover large areas persist almost exclusively in former military areas due to human activity (Adamska et al. 2015). The main factors responsible for that are trampling and the occurrence of accidental fires. After having been abandoned, this type of habitats quickly undergoes natural succession. As heathlands highly contribute to local diversity, they are actively protected and some management methods are applied to prevent their disappearance (Webb 1998). However, the outcomes of using these methods are different (Sedláková \& Chytrý 1999). One of the management activities is prescribed burn (Webb 1998, Ascolti et al. 2009). In the course of our study, it was applied for the first time in Poland and we undertook a successive fauna survey that encompasses several invertebrate groups.

The aim of this article is to present and document our findings of Collembola, supplement data on the distribution of the five recorded springtail species, summarize their habitat preferences and evaluate their prospective significance as indicator species for heath or associated habitats.

\section{Materials and methods}

We present data from two independent projects carried out in closely situated heath areas. The ultimate scope of the first of them - which is still in progress - is to examine the influence of prescribed burn on invertebrate fauna of the heath. The plot is situated in the former training military area in the northern part of Lower Silesia (W Poland; N 51'28'01', E 1542'02"; UTM: WT40). Three habitats were included in our study: a plot of an old and compact thicket of Calluna vulgaris shrubs, a plot where heather was rejuvenated with a controlled burn on 15.III.2015 and a plot, in which Molinia caerulea (L.) Moench grass almost totally dominates. The invertebrate fauna is surveyed by use of pitfall traps ( 7 independent traps per plot in a transect with $20 \mathrm{~m}$ spacing, one transect per plot). The traps are exposed all year round and checked every 3 weeks in the growing season, in winter the interval is slightly longer, i.e. about 1 month. Additionally, we sampled collembolans from vegetation onto a metal bowl in the same three plots as above and in their nearest surroundings.

Some records of Lepidocyrtus tellecheae Arbea \& Jordana, 1990 and Isotoma caerulea Bourlet, 1839 come from another project, in which interstitial Collembola of sand dunes, heath and pine forest were compared. This project was carried out in a nearby area (N 5125'34”, E 15³9'16”; UTM: WS49). We collected soil-litter samples from the microhabitats mentioned above and extracted springtails in Tullgren (Barlese) funnels. In this part of our study, there were a total of 312 samples, collected during 8 field sessions between April 2015 and March 2017.

Besides the two projects above, we list all the historic data of Seira dollfusi Carl, 1899 from the contemporary territory of Poland (they come from the former Prussia).

For close inspections, the springtails were cleared in Nesbitt's fluid and mounted on slides in a Barlese-Swan's medium (Swan 1936). We took multi-layer pictures of their diagnostic features, stacked them using the Helicon Focus 6.7.1. and prepared in Adobe Photoshop CS6. The springtails were identified using a set of keys (Gisin 1960, Bretfeld 1999, Potapov 2001, Fjellberg 2007, Mateos 2008, Cipola et al. 2018). All the records were compared with the current Polish checklist of Collembola (Sterzyńska et al.2007).

\section{The records}

\subsection{Bourletiella pistillum Gisin, 1964 (Bourletiellidae)}

We recorded 82 specimens of $B$. pistillum only in pitfall traps. It solely inhabits the plot where the 


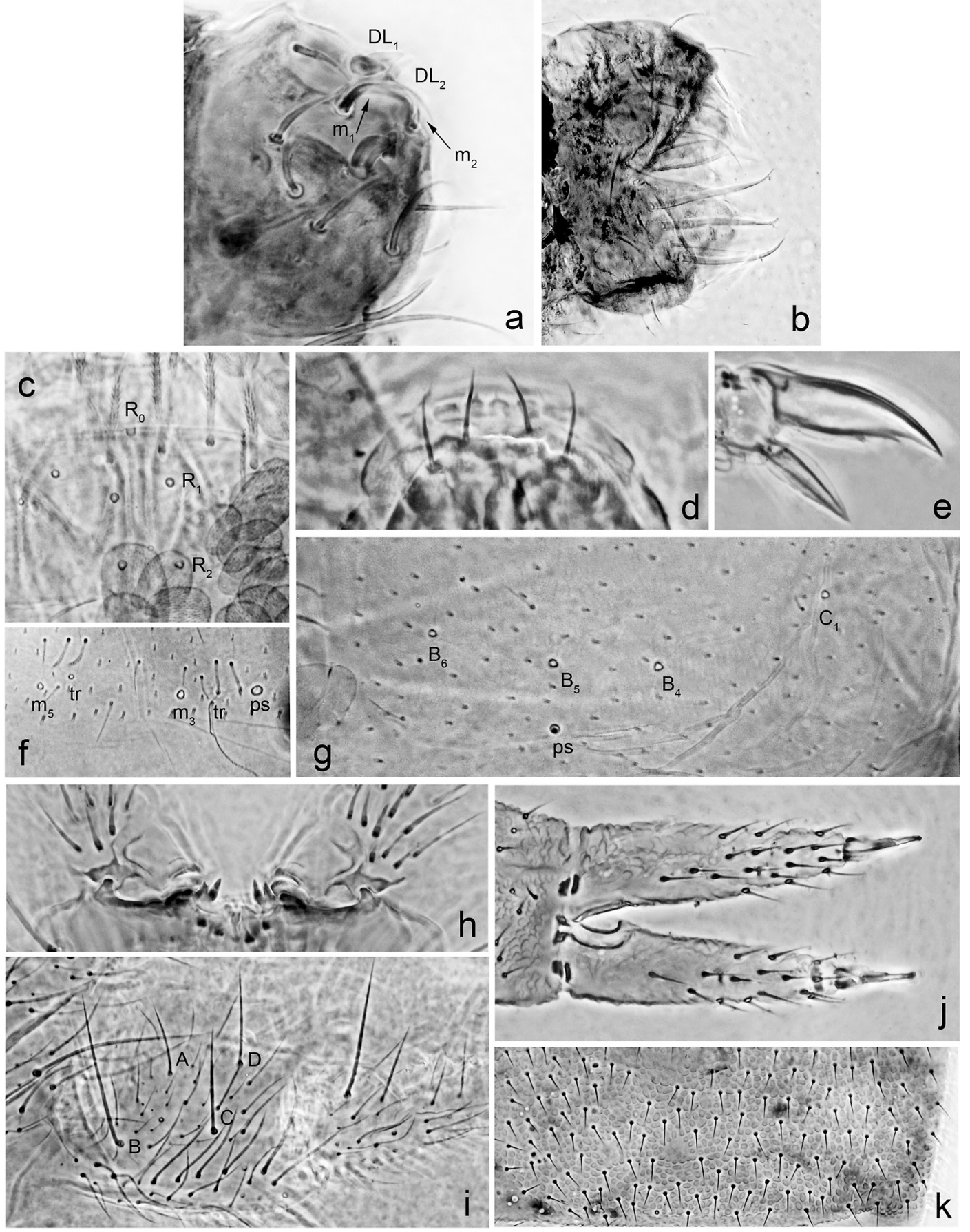

Fig. 1. Bourletiella pistillum. - a. Dorsal male organ on abdomen VI. - b. Female circumanal setae. Lepidocyrtus tellecheae. - c. Macrochaetae (chaetopores) in anterodorsal part of head. - d. Simple apical labral setae and papillae of labral edge. - e. Acuminate unguiculus. - f. Chaetotaxy of abdomen II (ps: pseudopore, tr: trichobothria). - g. Macrochaetae (chaetopores) on abdomen IV (left side). Isotoma caerulea. - h. Bispinose manubrial teeth. $-\mathrm{i}$. Macrochaetae on dorsal side of manubrium and basal part of dens. Pachyotoma topsenti. $-j$. Ventral side of dens and mucro. - k. Integument granulation (abdomen IV). Setal symbols a, c and i after Fjellberg (2007); $f$ and $g$ after Mateos (2008). 

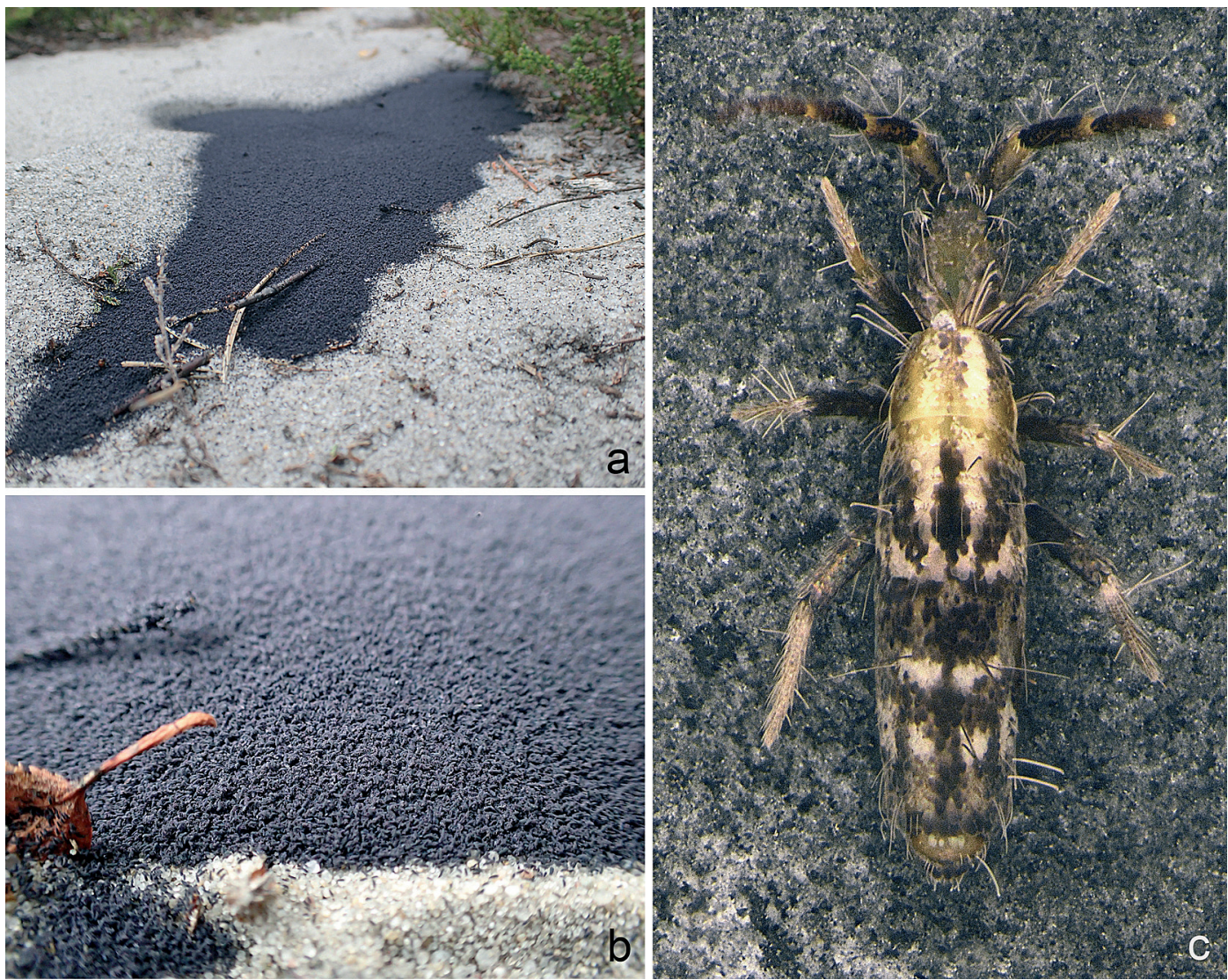

Fig. 2. Pachyotoma topsenti. - a, b. Aggregations on sand. Seira dolffusi. - c. Colour pattern, dorsal view.

prescribed burn was applied. The majority of the specimens occurred in a period between May and October, however we have observed a male in a trap, which was exposed from mid-December to late January.

The species is distinguished from the congeners by characteristic arrangement of setae on dorsal male organ on the sixth segment of abdomen (Fig. 1a) and the presence of differentiated circumanal setae in females (Fig. 1b).

This species is new to the fauna of Poland.

\subsection{Lepidocyrtus tellecheae Arbea \& Jordana, 1990 (Entomobryidae)}

Almost 7,000 specimens of L. tellecheae were collected in pitfall traps and 34 specimens were found in soil-litter samples. The species is gregarious with a maximum of about 700 individuals per trap in a single sampling period (i.e. three weeks). Lepidocyrtus tellecheae appeared in all of the studied plots in the first of our projects, with the highest numbers in the burnt plot and the area dominated by $M$. caerulea. In the other study it was present in a pine forest and in a heath on a sand dune. Our data suggest that it might have a winter activity peak - the majority of the specimens in pitfall traps were recorded between November and March - nevertheless we observed it throughout the year.

The species can be distinguished from the congeners by a pattern of macrochaetae on head (R0, R1, R2; Fig. 1c), and simple labral setae (Fig. 1d), macrochaeta $\mathrm{m} 3$ on the second segment of the abdomen (Fig. 1f), macrochaeta $\mathrm{C} 1$ on the fourth segment of the abdomen (Fig. 1g), and acuminate unguiculus (Fig. 1e).

This is the first record of this species in Poland. 
Table 1. Historic records (ordered westwards) of Seira dolfusi by Schubert (1933) in contemporary Poland and northeastern Czech Republic (Opawskie Mts).

\begin{tabular}{|c|c|c|c|}
\hline $\begin{array}{l}\text { Country } \\
\text { (contemporary) }\end{array}$ & $\begin{array}{l}\text { Mountain name } \\
\text { (Polish or Czech / orig. German) }\end{array}$ & $\begin{array}{l}\text { Approx. GPS } \\
\text { coordinates }\end{array}$ & Habitat \\
\hline Poland & $\begin{array}{l}\text { Góra Parkowa, Przednia Kopa / } \\
\text { Holzberg, Vorderkoppe } \\
\text { Długota / Langer Berg } \\
\text { Młyńska Góra / Mühlberg } \\
\text { Olszak / Birkberg }\end{array}$ & 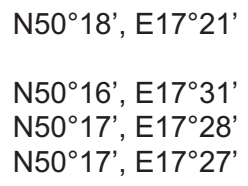 & $\begin{array}{l}\text { Quartzite rocks } \\
\text { Walls, solitary } \\
\text { rocks, scree in } \\
\text { former quarries }\end{array}$ \\
\hline $\begin{array}{l}\text { The Czech } \\
\text { Republic }\end{array}$ & $\begin{array}{l}\text { Špičák (?) by Supíkovice / } \\
\text { Spitzstein by Saubsdorf }\end{array}$ & $\mathrm{N} 50^{\circ} 17^{\prime}, \mathrm{E} 17^{\circ} 15^{\prime}$ & $\begin{array}{l}\text { A marble quarry, } \\
\text { among stones and } \\
\text { rock blocks }\end{array}$ \\
\hline
\end{tabular}

\subsection{Isotoma caerulea Bourlet, 1839 (Isotomidae)}

We recorded 205 specimens of $I$. caerulea in pitfall traps of all studied plots. There were 47 specimens in soil-litter samples from a heath and litter of a small group of Pinus sylvestris L. trees growing on a semi-open sand dune.

The species can be distinguished from the congeners, and especially Isotoma anglicana Lubbock, 1862 by the bispinose manubrial teeth (Fig. 1h), two dorsobasal macrochaetae on dens and manubrial dorsal macrochaetae $\mathrm{A}<\mathrm{B}$ (Fig. 1i).

The species is new to the fauna of Poland.

\subsection{Pachyotoma topsenti (Denis, 1948) (Isotomidae)}

This species was the most abundant collembolan species collected with pitfall traps. It has a very high propensity to aggregate, which we observed on a humid morning, on 15.VII.2017. In some places, it quickly filled small pits in the sand (Fig. 2a, b). In 64 samples where it was present, we observed over 53,000 specimens. Usually it aggregated with a maximum specimen number of about 8,000 per sample. The species occurred in all habitats investigated within the project concerning heath protection. The species was active all year round.

Pachyotoma topsenti can be easily distinguished from the congeners by the shape of mucro and number of setae (14-16) on the dentes
(Fig. 1j) with integument granulation of body surface specific for the genus (Fig. 1k).

\subsection{Seira dollfusi Carl, 1899 (Entomobryidae)}

We observed 153 specimens of $S$. dollfusi in pitfall traps. The species is common in the area, which was confirmed by some additional sampling onto a metal bowl from lower parts of vegetation (mainly $C$. vulgaris and $M$. caerulea).

The species has a very characteristic appearance, i.e. the colouring and scale pattern (Fig. 2c), which is sufficient to distinguish it from the congeners. We checked the identity of our specimens with the newly proposed key to Seira (Cipola et al.2018). Some features overlapped with those of Seira pallidipes Reuter, 1895, i.e. the presence of 8 or 9 macrochaetae on Abd IV in our specimens (see Discussion).

The majority of $S$. dollfusi specimens was observed in the period between April and October, but it was also active in winter months. Though it was recorded in the different habitats analyzed in the project in which pitfall traps were used, it occurred most frequently in the burnt site.

This is the first record of this species in the contemporary territory of Poland in 86 years after Schubert's (1933) publication, whose records are summarized in the Table 1 . There, the majority of the listed localities were situated in the former German part of the Opawskie Mountains (Zlatohorská vrchovina in Czech and Zuckmanteler Bergland in German). 


\section{Discussion}

During the study, we recorded five notable species of springtails. They are rarely encountered and three of them - Bourletiella pistillum Gisin, 1964 (Bourletiellidae), Isotoma caerulea Bourlet, 1839 (Isotomidae) and Lepidocyrtus tellecheae Arbea \& Jordana 1990 (Entomobryidae) are recorded in Poland for the first time. The fourth species, Seira dollfusi Carl, 1899 (Entomobryidae) is known in the region only from historic data. The fifth species, Pachyotoma topsenti (Denis, 1948) (Isotomidae), was known form Poland already prior to the present study, but the records were very infrequent. Occurrences of these five species may be of importance concerning conservation issues.

\subsection{Recognizing species and their identity}

Two of the analyzed species were described recently, so they require special care during identification. Isotoma caerulea was confused with I. anglicana until the revision by Fjellberg (2003), the result being supported shortly thereafter by a molecular-based research (Burkhardt \& Filser 2005).

The identity of $L$. tellecheae might be problematic, because this is a recently described species from Spain, assigned to the lignorum-group based on its colouration, size, chaetotactic pattern and smooth labral setae (Arbea \& Jordana 1990, Mateos 2011). The species identity has recently been verified by the molecular data. The authors suggested that there exist several further cryptic species (Mateos et al. 2018). Therefore, based on previous data and the huge geographical distance, we suggest that populations from Poland should undergo taxonomic analysis in the future, presumably using molecular methods. The species group in question has not yet been sufficiently analyzed and there are some data on its occurrence (L. cf. tellecheae) from Hungary (Traser \& Horvirth-Szovíti 2006, Dányi \& Traser 2007).

Seira dollfusi is another species, which may require more detailed analysis. The genus has been lately revised (Cipola et al. 2018), but due to problems with obtaining the type specimens much information concerning $S$. dollfusi is uncer- tain and some characters overlap with the features of the closely related $S$. pallidipes. Based on the latest key proposed by Cipola et al. (2018) and the general appearance of the investigated animals, we conclude that the specimens we analysed belong to $S$. dollfusi. Nevertheless, not all features perfectly fit those suggested by Cipola et al. (2018). As mentioned above the number of macrochaetae on Abd IV was higher than suggested, i.e. instead of 7 we observed 8 or 9 . The variability in this feature may be too high to use it for identifying species.

\subsection{Distributions}

Many records of $B$. pistillum come either from the North of Europe or from mountains (Fjellberg 2007), which could suggest that it is a boreomontane species. However, there are a few records from Central European lowlands and their common feature seems to be that they come from open and xerothermic habitats (see below).

Isotoma caerulea has probably a wide range, although older records are uncertain due to confusion with I. anglicana. Fjellberg (2003) mentions its presence in Scandinavia and most of Western Europe. It was also noted in Moldavia (Bușmachiu \& Weiner 2013) and Hungary (Winkler \& Tóth 2012). Moreover, there are records from the USA and Greenland (Fjellberg 2003).

The records of $P$. topsenti in Europe are scarce. The species has been noted only in few countries, i.e. Germany, France, Poland and Switzerland (Denis 1948, Dunger 1987, Potapov 2001, Sterzyńska et al. 2007), and in each of those there are just single localities of the species.

Lepidocyrtus tellecheae has only been recorded in the North and North-East of the Iberian Peninsula (Arbea \& Jordana 1990, Mateos et al. 2018) and was thought to be endemic to the region (Mateos 2008). The huge gap in its range is striking and provokes taxonomical questions. However, the reasons for this untypical distribution may also have its source in insufficient knowledge on collembolan fauna generally. As mentioned before, this is not the first report on the species from Central Europe (Traser \& HorvíthSzovíti 2006, as Lepidocyrtus cf. tellecheae).

Seira dollfusi reaches its northern range in 
Central Europe and its known populations are scattered in the region. The northernmost data come from the Eastern Sudetes in Southern Poland by Schubert (1933). Our data expand this range in the country further to the North. The presence of $S$. dollfusi in this part of Europe has been questionable to date (Sterzyńska et al. 2007).

\subsection{Habitats}

The five species in question seem to prefer slightly different habitat types. In the heathland studied by us, B. pistillum inhabited solely the burnt area, which suggests that it is a pioneer species. Indeed, it has been previously reported from mining dumps in Eastern Germany, where it dominated. The species colonized the plots as one of the first animals (Dunger et al. 2002, Wanner $\&$ Dunger 2002). In Spain, the species was present in pine forests that underwent fires while it was not found in control (unburned) plots or in other forest types (Mateos \& Selga 1991). On the other hand, in a burnt montane forest with dwarf pine shrubs it clearly preferred an undisturbed plot (Querner et al. 2010). The record, however, comes from high altitudes in the Alps, thus the species habitat preferences might be different there. Some authors indicate that the species is characteristic for dry habitats (Wanner et al. 1999).

Apart from this, the species seems to prefer northern parts of Europe and mountains (Ellis 1975, Fjellberg 2007), inhabiting dry slopes or rocks in lowlands (Fjellberg 2007), subalpine and alpine meadows (Gisin 1960, Fjellberg 1976) or montane heaths (Ellis 1975, Fjellberg 1976, 2007). Large numbers of $B$. pistillum were reported from the canopy of pine trees in Norway (Thunes et al. 2004). Pine forests are also prevalent in our study area. Summing up, the species is known from numerous localities in the North and mountains and it can be found also in other altitudes and latitudes, where it is known to colonise disturbed areas.

Data on L. tellecheae are very scarce. The above-mentioned specimens of uncertain identity from Hungary (Traser \& Horvíth-Szovíti 2006) came from a region with sandy calcareous soils.

Pachyotoma topsenti was recorded by
Dunger (1987) in Eastern Germany from very similar habitats as in the case of our study, i.e. pine and spruce plantation, with sparsely growing trees. The author also observed a mass occurrence of the species, the phenomenon mentioned already by the author of the species name, Denis (1948). The species seems to prefer open habitats and it disappears with the succession of pine forests (Sławska \& Sławski 2016).

Isotoma caerulea inhabits xerothermic environments, predominately with dry and sandy soils, as opposed to its near relative, I. anglicana, which prefers humid soils, rich in organic matter (Fjellberg 2003, 2007). The author recorded this species on seashore meadows in Norway. Slightly contradictory information on the two Isotoma species is presented, however, by Burkhardt and Filser (2005). Buşmachiu and Weiner (2013) report its presence in Dniester river banks in Moldavia. It has been noted in grasslands on Iceland (Gudleifsson \& Bjarnadottir 2008), meadows, pastures and road verges in Finland (Komonen \& Kotaja-aho 2017) and steppe meadows in Hungary (Winkler \& Tóth 2012). Franken and Berg (2018) noted it also on Dutch sand dunes. It was one of the dominant species in moss in calcareous grasslands in Sweden (Cronberg et al. 2008).

Open warm and dry habitats seem to provide suitable conditions for I. caerulea, making it a good indicator of such environments. It may be cautiously assumed that some I. anglicana found so far in environments like sand dunes, heathlands or dry pine forests may have been I. caerulea.

Seira dollfusi is considered a South European springtail (Stach 1928), which in Central Europe lives in habitats affording proper thermal conditions, usually on sun exposed walls of quarries or rocks (Schubert 1933). Dry heathlands in Central Europe seem to afford proper thermal conditions to sustain numerous populations of the species. It is not the only example of arthropod species, which inhabits both exposed rocky habitats in the mountains and lowland heathlands or sandy habitats in Central Europe. The spider species Philaeus chrysops Poda, 1791 may serve as an example for this type of habitat preference in Poland, although it has a slightly broader habitat range. 


\subsection{Significance}

Among springtails, there is a number of rarely found species, which often inhabit some unique habitats or habitat types. Understanding their biology, including the preferred habitats, may facilitate further analysis of their assemblages. In the Central European heathlands we report five species of interest, because of their rarity, new taxonomic status or potential indicator value. Bourletiella pistillum may be regarded as a facultative pioneer species of disturbed areas, I. caerule $a$ and $S$. dollfusi may serve as an indicator species of xerothermic habitats in Central Europe. Lepidocyrtus tellecheae has a rather unusual distribution pattern and the systematics of this species should be reconsidered. Pachyotoma topsenti is characteristic for its aggregations and indicates dry, open habitats, which may easily undergo succession by a forest.

Acknowledgements. The inventory of springtails is a part of the project "Establishing the fire protection rules for the protected areas and objects, and use of prescribed burn as an active nature conservation method" led by the Institute of Forestry Research in Sękocin and financed by the General Directory of the National Forests. We would like to thank Angelika Dawidowicz, Adam Malkiewicz, Dariusz Skarżyński and Ewa Szczęśniak from the University of Wrocław, and the staff of the Forest District in Przemków and the Regional Department of the National Forests in Wrocław. We would like to express our sincere thanks to the two anonymous reviewers for their valuable suggestions.

\section{References}

Adamska, E., Deptuła, M., Filbrandt-Czaja, A., Kamiński, D., Lewandowska-Czarnecka, A., Nienartowicz, A. \& Sewerniak, P. 2015: Heathlands and associated communities in Kujawy and Pomerania: management, treatment and conservation. - Towarzystwo Naukowe w Toruniu, Toruń. 236 pp.

Arbea, J. I. \& Jordana, R. 1990: New species of Pseudosinella and Lepidocyrtus from Navarra (Northern Iberian Peninsula). - Spixiana 13(1): 25-31.

Ascolti, D., Beghin, R., Ceccato, R., Gorlier, A., Lombardi, G., Lonati, M., Marzano, R., Bovio, G. \& Cavallero, A. 2009: Developing an adaptive management approach to prescribed burning: a long-term heathland conservation experiment in north-west Italy. - International Journal of Wildland Fire 18 (6): 727-735. doi: https://doi.org/10.1071/WF07114

Bretfeld, G. 1999: Synopses on Palaearctic Collembola.
Vol. 2: Symphypleona. — Staatliches Museum für Naturkunde Görlitz, Görlitz. 318 pp.

Buchholz, S., Hannig, K. \& Schirmel J. 2013: Losing uniqueness - shifts in carabid species composition during dry grassland and heathland succession. - Animal Conservation 16(6): 661-670. doi: https:/doi.org/ 10.1111/acv.12046

Burkhardt, U. \& Filser, J. 2005: Molecular evidence for a fourth species within the Isotoma viridis group (Insecta, Collembola). - Zoologica Scripta 34(2): 177-185. doi: https://doi.org/10.1111/j.1463-6409.2005.00181.x

Buşmachiu, G. \& Weiner, M. W. 2013: Collembola from the Moldavian banks of Dniester River. New records. - Annales Zoologici 63(4): 529-535. doi: https:// doi.org/10.3161/000345413X676759

Cipola, N. G., Arbea, J., Baquero, E., Jordana, J., de Morais, J. W. \& Bellini, B. C. 2018: The survey of Seira Lubbock, 1870 (Collembola, Entomobryidae, Seirinae) from Iberian Peninsula and Canary Islands, including three new species. - Zootaxa 4458(1): 1-66. doi: https://doi.org/10.11646/zootaxa.4458.1.1

Cronberg, N., Natcheva, R. \& Berggren, H. 2008: Observations regarding the life cycle of silvermoss Bryum argenteum. - In: Mohamed, H., Baki, B. B., Nasrulhaq-Boyce, A. \& Lee, P. K. Y. (eds), Bryology in the New Millennium: 347-352. University of Malaya, Kuala Lumpur. 513 pp.

Denis, J. R. 1948: Sur la faune francaise des Apterygotes (XXIII). - Bulletin scientifique de Bourgogne: 4551. [In French.]

Dányi, L. \& Traser, G. 2007: An annotated checklist of the springtail fauna of Hungary (Hexapoda: Collembola). - Opuscula Zoologica Budapest 38: 3-82.

Dunger, W. 1987: Proisotoma topsenti Denis, 1948, eine seltene, zu Übervermehrung neigende Art der Collembola (Insecta). - Abhandlungen und Berichte des Naturkundemuseums Görlitz 60(12): 53-60.

Dunger, W., Schulz, H.-J. \& Zimdars, B. 2002: Colonization behaviour of Collembola under different conditions of dispersal. — Pedobiologia 46: 316-327.

Dunger, W. \& Voigtländer, K. 2009: Soil fauna (Lumbricidae, Collembola, Diplopoda and Chilopoda) as indicators of soil eco-subsystem development in post-mining sites of eastern Germany - a review. - Soil Organisms 81(1): 1-51. https://doi.org/10.1078/00314056-00139

Ellis, W. N. 1975: On Bourletiella (Cassagnaudiella) pruinosa (Tullberg, 1871) and its allies (Collembola: Sminthuridae). - Bulletin Zoölogisch Museum, Universiteit van Amsterdam 4(9): 69-81.

Fjellberg, A. 1976: Collembola from mountains in South Norway. - Norwegian Journal of Entomology 23: 127-137.

Fjellberg, A. 2003: Revision of six northern species of the Isotoma viridis Bourlet, 1839 complex (Collembola, Isotomidae). - Norwegian Journal of Entomology 50: 91-98.

Fjellberg, A. 2007: The Collembola of Fennoscandia and Denmark, part II: Entomobryomorpha and Symphypleona. - Fauna Entomologica Scandinavica 42. 
Brill, Leiden, Boston. 264 pp. doi: https://doi.org/ 10.1163/ej.9789004157705.i-265

Franken, O. \& Berg, M. P. 2018: Entomofauna van de Noord-Hollandse duinen. Verslag van de 171e NEVzomerbijeenkomst. - Entomologische Berichten 78(2): 42-69. [In Dutch with English summary.]

Gisin, H. 1960: Collembolenfauna Europas. — Museum d'histoire naturelle, Geneve. 312 pp. [In German.]

Gudleifsson, B. E. \& Bjarnadottir, B. 2008: Springtail (Collembola) populations in hayfields and pastures in northern Iceland. - Icelandic Agricultural Sciences 21: 49-59.

Huebner, K., Lindo, Z. \& Lechowicz, M. J. 2012: Post-fire succession of collembolan communities in a northern hardwood forest. - European Journal of Soil Biology 48: 59-65. doi: https://doi.org/10.1016/j.ejsobi. 2011.10 .004

Komonen, A. \& Kataja-aho, S. 2017: Springtails (Collembola) in meadows, pastures and road verges in Central Finland. - Entomologica Fennica 28: 157-163.

Krause, R. H. \& Assmann, T. 2016: Impact of prescribed burning on a heathland inhabiting spider community. - Arachnologische Mitteilungen / Arachnology Letters 51: 57-63. doi: https://doi.org/10.5431/aramit 5108

Mateos, E. 2008: The European Lepidocyrtus Bourlet, 1839 (Collembola: Entomobryidae). - Zootaxa 1769: 35-59. doi: https://doi.org/10.11646/zootaxa. 1769.1.2

Mateos, E. 2011: New Lepidocyrtus Bourlet, 1839 taxa from Greece (Collembola: Entomobryidae). — Zootaxa 3108: 25-40. doi: https://doi.org/10.11646/zootaxa.3108.1.2

Mateos, E., Escuer, P., Buşmachiu, G., Riutort, M. \& Álvarez-Presas, M. 2018: Untangling Lepidocyrtus (Collembola, Entomobryidae): new molecular data shed light on the relationships of the European groups. - Invertebrate Systematics 32: 639-651. doi: https:// doi.org/10.1071/IS17056

Mateos, E. \& Selga. D. 1991: Efecto de los incendios forestales sobre las problaciones de colémbolos edáficos en bosque mediterráneo. - Revue d'Ecologie et de Biologie du Sol 28(1): 19-30. [In Spanish.]

Petersen, H. 1995: Temporal and spatial dynamics of soil Collembola during secondary succession in Danish heathland. - Acta Zoologica Fennica 196: 190-194.

Piwnik, A. \& Skarżyński, D. 2011: Skoczogonki (Collembola) wydm śródlądowych specjalnego obszaru ochrony Wrzosowisko Przemkowskie. - Parki Narodowe i Rezerwaty Przyrody, 30(3-4): 122-128. [In Polish with English summary.]

Piwnik, A. \& Skarżyński, D. 2015: Psammophilic springtails (Collembola) new to Polish fauna. - Wiadomości Entomologiczne 34(1): 5-11. [In Polish with English summary.]

Ponge, J.-F., Tully, T. \& Gins, A. 2008: Short-term responses of two collembolan communities after abrupt environmental perturbation: A field experimental approach. - Pedobiologia 52: 19-28. doi: https:// doi.org/10.1016/j.pedobi.2008.01.005
Potapov, M. B. 2001: Synopses on Palaearctic Collembola. Vol. 3. Isotomidae. - Staatliches Museum für Naturkunde Görlitz, Görlitz. 603 pp.

Russell, D. J. 2008. Collembolan community structures in a continental psammic habitat of south-west Germany. — Soil Organisms 80(1): 117-131.

Querner, P., Bruckner, A., Weigand, E. \& Prötsch, M. 2010: Short- and long-term effects of fire on the Collembola communities of a sub-alpine dwarf pine ecosystem in the Austrian Alps. - Eco.mont - Journal of protected mountain areas research and management 2(2): 29-36. doi: https://doi.org/10.1553/eco.mont-22s 29

Schirmel, J. 2010: Short-term effects of modern heathland management measures on carabid beetles (Coleoptera: Carabidae). - Applied Ecology and Environmental Research 8(3): 165-175.

Schubert, K. 1933: Ökologische Studien an schlesischen Apterygoten. - Deutsche Entomologische Zeitschrift 2-3: 177-272. doi: https://doi.org/10.1002/mmnd. 193419330203

Sedláková, I. \& Chytrý, M. 1999: Regeneration patterns in a Central European dry heathland: effects of burning, sod-cutting and cutting. - Plant Ecology 143: 77-87. doi: https://doi.org/10.1023/A:1009807411654

Shaw, P. J. A. 1997: Post-fire successions of Collembola in lowland heaths in South-Eastern UK. - Pedobiologia 41: 80-87.

Sławska, M. 1996: Succession of Collembola in an active deflation hollow in Słowiński National Park. - Pedobiologia 41(1-3): 139-144.

Sławska, M. \& Sławski, M. 2016: Powrót lasu na zaniechane rolniczo sandrowe gleby Równiny Charzykowskiej. - Studia i Materiały CEPL w Rogowie 46(1): 147-162. [In Polish.]

Stach, J. 1928: Verzeichnis der Apterygogenea Ungarns. - Annales Musei Nationalis Hungarici 26: 269-312.

Sterzyńska, M., Pomorski, R.J., Sławska, M., Skarżyski, D., Smolis, A. \& Weiner, W.M. 2007: Skoczogonki (Collembola). - In: Bogdanowicz, W., Chudzicka, E., Pilipiuk, I. \& Skibińska, E. (eds), Fauna of Poland - characteristics and checklist of species: 401-415. Museum and Institute of Zoology PAS, Warsaw. $505 \mathrm{pp}$.

Swan, D. A. 1936: Barlese's fluid: remarks upon its preparation and use a mounting medium. - Bulletin of Entomological Research 27(3): 389-391. doi: https:// doi.org/10.1017/S0007485300058259

Swengel, A. B. 2001: A literature review of insect responses to fire, compared to other conservation managements of open habitat. - Biodiversity and Conservation 10: 1141-1169. doi: https://doi.org/10.1023/ A:1016683807033

Thunes, K. H., Skartveit, J., Gjerde, I., Starý, J., Solhřy, T., Fjellberg, A., Kobro, S., Nakahara, S., zur Strassen, R., Vierbergen, G., Szadziewski, R., Hagan, D.V., Grogan Jr., W. L., Jonassen, T., Aakra, K., Anonby, J., Greve, L., Aukema, B., Heller, K., Michelsen, V., Haenni, J.-P., Emeljanov, A. F., Douwes, P., Berggren, K., Franzen, J., Disney, R. H. L., Prescher, S., Johan- 
son, K. A., Mamaev, B., Podenas, S., Andersen, S., Gaimari, S. D., Nartshuk, E., Sřli, G. E. E., Papp, L., Midtgaard, F., Andersen, A., von Tschirnhaus, M., Bächli, G., Olsen, K. M., Olsvik, H., Földvári, M., Raastad, J. E., Hansen, L. O. \& Djursvoll, P. 2004: The arthropod community of Scots pine (Pinus sylvestris L.) canopies in Norway. - Entomologica Fennica 15: 65-90.

Traser, G. \& Horvrth-Szovíti, E. 2006: Land-use intensity and diversity parameters: Collembola (Insecta) communities in Csévharaszt (Hungary). — In: Csóka, Gy., Hirka, A. \& Koltay, A. (eds.), Biotic damage in forests: 329-339. Proceedings of the IUFRO (WP7. 03.10) Symposium held in Mátrafüred, Hungary, September 12-16, 2004. 360 pp.

Usher, M. B. 1992: Management and diversity of arthropods in Calluna heathland. - Biodiversity and Conservation 1: 63-79. doi: https://doi.org/10.1007/ BF00731035
Wanner, M. \& Dunger, W. 2002: Primary immigration and succession of soil organisms on reclaimed opencast coal mining areas in eastern Germany. - European Journal of Soil Biology 38: 137-143. doi: https:// doi.org/10.1016/S1 164-5563(02)01135-4

Wanner, M., Hauser, H., Zimdars, B. \& Dunger, W. 1999: Einwanderungswege der Bodenfauna auf Kippen des Tagebaues Berzdorf. - Berichte der Naturforschenden Gesellschaft der Oberlausitz 7/8: 101-104.

Webb, N. R. 1998: The traditional management of European heathlands. - Journal of Applied Ecology 35: 987-990. doi: https://doi.org/10.1111/j.1365-2664. 1998.tb00020.x

Winkler, D. \& Tóth, V. 2012: Effects of afforestation with pines on Collembola Diversity in the limestone hills of Szárhalom (West Hungary). - Acta Silvatica et Lignaria Hungarica 8: 9-20. doi: https://doi.org/10.2478/ v10303-012-0001-8 